\title{
Growth Partitioning Three Years Following Structural Pruning of Quercus virginiana
}

\author{
Edward F. Gilman and Jason Grabosky
}

\begin{abstract}
One codominant stem on each of 48 similar Quercus virginiana Highrise ${ }^{\circledast}$ trees was pruned to evaluate impact of pruning severity on growth suppression and partitioning. Targeted pruning severity $(0,25,50$ or $75 \%$ foliage and subtending branches removed) based on visual estimates of two people correlated well $\left(r^{2}=0.87\right)$ with the ratio stem cross-sectional area removed: cross-sectional area at base of the pruned codominant stem. Pruning reduced cross-sectional area growth on codominant stems compared to the leader stem that was not pruned, especially during the first 12 months following pruning. Increased pruning severity reduced cross-sectional area growth on the pruned stem in proportion to amount of foliage removed. In each of three years following pruning, cross-sectional area of the unpruned leader stem increased more on trees receiving targeted pruning severities of $25 \%$ or $50 \%$ than trees pruned with the $75 \%$ severity or trees not pruned. Shift in growth from the pruned to unpruned portion of the tree reduced diameter ratio between the two stems, which should make the union stronger. Diameter ratio changed most for the $75 \%$ pruning severity.

Key Words: Branch Union; Codominant Stem; Diameter Ratio; Leader Stem; Reduction Cut; Removal Cut; Subordination.
\end{abstract}

Branches are well-attached to the tree when they are small in comparison to the trunk (Gilman 2003; Kane et al. 2008). This results from shade suppressing branch growth in the forest encouraging growth in a dominant trunk. Codominant stems on trees result in a weak union (Kane et al. 2008), especially when accompanied with bark inclusions (Smiley 2003). However, there is little research on pruning strategies for urban trees such as growth suppression on codominant stems. Most pruning studies were conducted in forested stands, not on open grown landscape trees.

Rom and Ferree (1985) reported leaf, shoot, root, and total dry weight in the year after pruning peach in an orchard decreased as pruning severity (dose) increased. Stem diameter growth generally slows with increased crown raising severity (crown raising pruning type as described in American National Standards Institute 2008), and the effect in the forest can last two or more years (Langstrom and Hellqvist 1991; O'Hara 1991). In contrast, Pinkard and Beadle (1998) reported increased cross-sectional area growth in tops of forest trees with increased crown raising severity. There is little research on growth impacts of raising or any other pruning type on open-grown landscape trees. It is not clear whether raising conducted in the forest relates well to open grown trees common in arboriculture, but it is one of the only guidelines available in the literature.

Pruning did not alter trunk diameter or tree height of rose gum (Eucalytpus grandis W. Hill ex Maiden) (Bredenkamp et al. 1980), nor crown volume of black walnut (Juglans nigra L.) (Funk 1979). Neilsen and Pinkard (2003) showed that light crown raising (removing all branches in the lower $45 \%$ of tree height) had no effect on growth of Monterey pine (Pinus radiata) D. Don, but heavier pruning ( $60 \%$ or $75 \%$ removal) decreased trunk diameter growth, stem volume, and tree height in the forest.

Clark (1955) and Funk (1979) found that increasing amount of lower branches removed corresponded to re- duced trunk taper of black walnut and more sprouting along the trunk. In contrast, some researchers found that neither stem taper (Pinkard and Beadle 1998) nor total timber yield (Bredenkamp et al. 1980) was affected by crown raising.

Pruning one side of the crown to encourage the other side to grow faster has been referred to as structural pruning (Gilman and Lilly 2008), but there is little research supporting this contention. One study on seedlings grown in an open landscape on California coastal live oak (Quercus agrifolia N'ee) and valley oak ( $Q$. lobata $\mathrm{N}^{\prime}$ ee) found that headed or thinned codominant stems grew slower than stems that were not pruned (Downer et al. 1994). Structural pruning seeks to enhance growth on the unpruned leader by reducing growth rate on pruned low branches and on pruned codominant stems higher in the crown. The pruning severity required to cause this growth reduction has not been thoroughly studied.

The objective of the current study was to determine impact of pruning severity on tree growth partitioning over time.

\section{MATERIALS AND METHODS}

Quercus virginiana Mill. is a common tree in USDA hardiness zones $7-10$, and readily develops codominant stems, making the tree a good subject for study. In May 2005, forty-eight $11 \mathrm{~cm}(4.4$ in) trunk caliper $(\mathrm{SD} 1 \mathrm{~cm}), 7 \mathrm{~m}(23 \mathrm{ft})$ tall (SD $48 \mathrm{~cm})$, seven-yearold Quercus virginiana Mill. Highrise ${ }^{\circledR}$ live oaks planted three years earlier and $4.9 \mathrm{~m}(16 \mathrm{ft})$ apart were pruned to remove branch biomass of one codominant stem. All trees were surface-fertilized

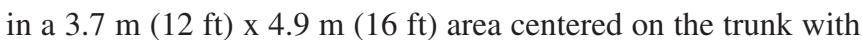
$1 \mathrm{~kg}(2.4 \mathrm{lbs})$ of 16:4:8 (N:P:K) one or two times a year between 2003 and 2007. On each tree, the two largest and similarly sized codominant stems growing from the same union were located, and a diameter tape was used to measure diameter at the base of each stem, $5 \mathrm{~cm}$ ( 2 in) beyond any swelling associated with the union. 
The smaller of the codominant stems ("the codominant") averaged $47 \mathrm{~mm}(1.9 \mathrm{in})$ in diameter $(\mathrm{SD}=13 \mathrm{~mm})$, and was pruned according to the targeted severity. The larger of the codominant stems ("the leader") averaged $62 \mathrm{~mm}$ (2.4 in) in diameter (SD $=16 \mathrm{~mm}$ ), and was not pruned. The smaller stem was chosen for pruning to eliminate any possible effect of diameter ratio on growth response. Both stems were marked close to the union so they could be measured in subsequent years at the same position.

Pruning was applied by removing branches on the pruned codominant stem as one of four visual targeted pruning severities (TPS): $0 \%$ (control), $25 \%, 50 \%$, or $75 \%$ of total foliage removed. Severities were visual estimates of the percentage of foliage removed from the pruned codominant stem. Visual estimates were made by two assessors standing next to the tree as stems were removed. Both assessors had to agree on the severity before pruning was considered complete. To quantify amount of biomass removed, a cross-sectional area (CSA) of each pruning cut (outside bark) was calculated using a diameter tape and summed for each pruned tree. Ratio of CSA removed to CSA at base of the codominant was termed CSAR. Pruning severities were arranged in a randomized complete block design with 12 blocks and four trees per block. One tree in each block randomly received one of four severities.

One to five pruning cuts (mean 2.9) were made on each pruned stem to attain the TPS; most cuts were reduction cuts and some were removal cuts (Gilman and Lilly 2008). The largest diameter, most upright portion of the codominant stem closest to the unpruned leader was removed first; others were removed, typically toward the end of the codominant stem, as needed to attain targeted severity. This structural pruning type is described in detail in Gilman and Lilly (2008). In September 2006, June 2007, and May 2008, diameters of pruned codominant stem and unpruned leader on each tree were measured in the same position as described above.

The relationship between branch or stem diameter and fresh foliage mass was calculated by choosing three trees at random from the source nursery field. Six branch and 6 stem segments were paired (for a total of 12) by equal diameter for the following diameters: $0.8 \mathrm{~cm}(0.3 \mathrm{in}), 1.5 \mathrm{~cm}$ (0.6 in), $2.3 \mathrm{~cm}(0.9$ in), $3.0 \mathrm{~cm}$ (1.2 in), $3.8 \mathrm{~cm}$ (1.5 in), and $4.6 \mathrm{~cm}$ (1.8 in); these represented orthogonal values within the range of pruning cut diameters. Diameter was measured with a diameter tape at the base of each branch or stem $5 \mathrm{~cm}$ beyond any swelling associated with the union. Branches were less than one-third diameter of trunk measured just above the union, and stems were at least three times branch diameter at the union. All leaves were carefully pulled from the segment distal to the diameter measurement and weighed fresh. Fresh weight was used because arborists work with live trees. A least squares regression line was fitted to stem or branch diameter and foliar fresh weight separately, then data combined for stems and branches because slopes of both relationships were statistically similar (t-test, $P>0.05$; slope and intercept $P>0.05$ ).

The percent increase in CSA growth of the codominant stem was calculated as [(CSA end of project - CSA at initial pruning) $\div$ CSA at initial pruning] x 100 . Each year, CSA growth of the pruned codominant stem and unpruned leader stem was calculated as CSA current - CSA previous measurement. Stem diameter was measured with a diameter tape at the base of each pruned and unpruned stem $5 \mathrm{~cm}$ beyond any swelling associated with the union. Trunk diameters were measured at the beginning of project and annually with a diameter tape at $30 \mathrm{~cm}$ (12 in) from ground.
CSAR was regressed onto TPS. Fresh leaf mass was regressed onto CSA of branches from which leaves were removed. The percent increase in CSA growth of the codominant stem was regressed onto CSAR. Linear relationships were analyzed with Minitab version 14 (Minitab Inc., State College, PA) and considered significant at $P<0.05$. CSA on the codominant and leader, and ratio of diameter of the codominant to the diameter of the leader stem were analyzed by repeated measures two-way analysis of variance within a randomized complete block design using GLM in SAS 9.1.3 (SAS Institute, Cary, NC) with $P<0.05$. Main effects were pruning severity and time. Trunk diameter was analyzed by repeated measures oneway analysis of variance with pruning severity as the main effect. Means were compared using Tukey's multiple range test.

\section{RESULTS}

The number of pruning cuts required to achieve TPS increased with pruning severity from 2.7 for $25 \%$ severity to 2.9 for $50 \%$ severity, and 3.6 for $75 \%$ severity. Pruning cut diameter ranged from $8 \mathrm{~mm}(0.3 \mathrm{in})$ to $48 \mathrm{~mm}$ ( $1.9 \mathrm{in})$ across trees in all treatments.

CSAR correlated well with TPS but varied widely within each TPS (Figure 1). This large range is attributed to variation in the visual estimate of foliage removed because there was an excellent relationship between CSA removed and actual foliage mass removed (Figure 2). Since slope in Figure 1 was close to one (0.99), mass of foliage removed from a live oak stem might be predictable visually by a trained assessor, although Smiley and Kane (2006) also found considerable variability in visual estimates. The CSAR of one pruned stem exceeded the CSA of the stem base and on two other pruned stems was close to $100 \%$ CSAR (Figure 3 ). Since these were all $75 \%$ pruning severity treatments, there was a visual $25 \%$ of foliage remaining on these three stems.

Increasing pruning severity slowed percent increase in CSA growth in proportion to amount of foliage removed on the pruned codominant stem (Figure 3). CSA growth on pruned codominant stems at 25,50 , and $75 \%$ TPS was less than on codominant stems on unpruned control trees in the first growing season after pruning (Figure 4A). This indicated that pruned codomi-

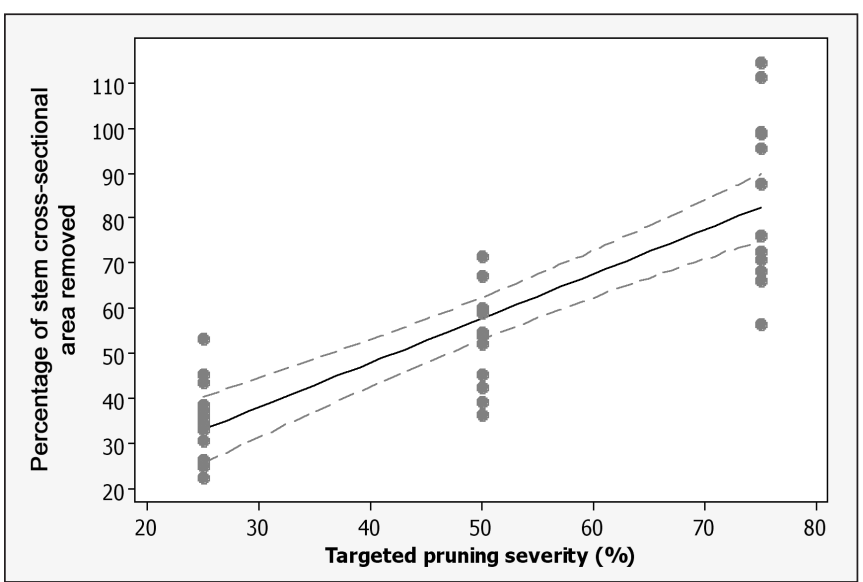

Figure 1. Relationship between percentage of cross-sectional area removed on the codominant (CSAR) and targeted pruning severity (TPS). CSAR $=0.99$ (TPS) $+8.18 . r^{2}=0.69$, slope $P<0.001$, intercept $P=0.19$. The dashed lines represent a $95 \%$ confidence interval for the regression equation. 


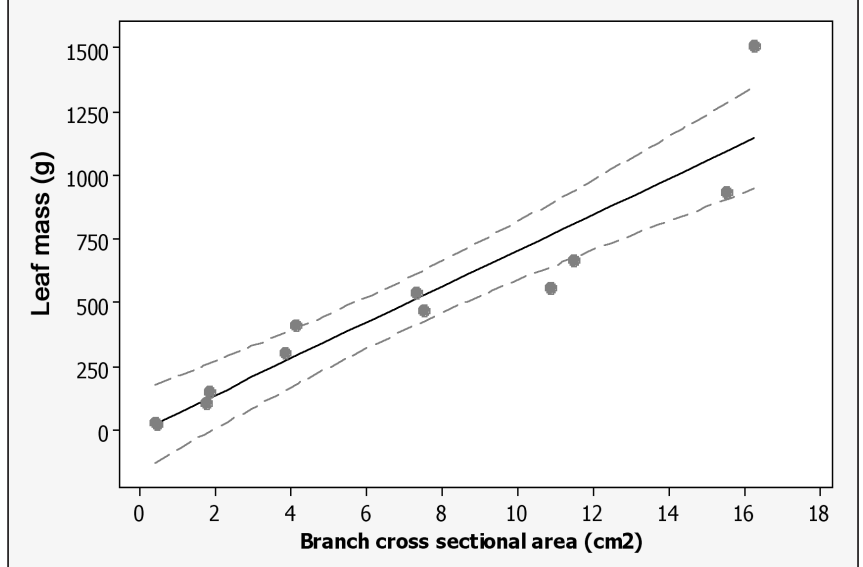

Figure 2. Relationship between fresh leaf mass and branch crosssectional area (CSA). Leaf mass $=70.81(C S A)-5.9, r^{2}=0.88$, slope $P<0.001$, intercept $P=0.93$. The dotted lines represent a $95 \%$ confidence interval for the regression equation.

nant stems grew more slowly than codominant stems that were not pruned. CSA growth on pruned codominant stems was not affected at $25 \%$ or $50 \%$ pruning severities in the second year following pruning compared to unpruned trees, but stems receiving $75 \%$ severity grew slower than unpruned trees (Figure 4B). The 50\% and $75 \%$ severities both grew more slowly than unpruned controls in the third year after pruning (Figure 4C).

Pruning the codominant enhanced CSA growth in the unpruned leader (compared to the leader stem in unpruned trees) on trees receiving $25 \%$ and $50 \%$ pruning severities in all three years (Figure 4A-D). Resources appeared to be preferentially allocated to the unpruned leader at these lower pruning severities. This shift in growth from the pruned to unpruned portion of the tree reduced the diameter ratio of codominant to the leader for all TPS, except unpruned trees (Figure 5). Most of the reduction in diameter ratio occurred in the first year after pruning, and diameter ratio for $25 \%$ and $50 \%$ TPS remained unchanged in years two and three following pruning, which is reflected in the interaction between TPS and year. Trees that received 25\% TPS on the codominant grew more in trunk diameter (caliper) beginning in the first year following pruning than trees that were not pruned and trees that were pruned more severely (Figure 6).

Pruning the codominant with $75 \%$ severity did not affect CSA growth in the unpruned leader (compared to the leader stem in unpruned trees) (Figure 4). However, diameter stem ratio in trees that received $75 \%$ TPS continued to decrease with time so that by the third year it was significantly lower than in any other treatment (Figure 5). Change in diameter ratio was larger for larger pruning severities.

\section{DISCUSSION}

Net dry mass assimilation rate was not impacted by light lateral branch shortening ( $28 \%$ foliage and subtending branches removed) on single leader three-year-old alder (Alnus glutinosa L. Gaerten) (Singh and Thompson 1995). In contrast, Rom and Ferree (1985) showed that photosynthesis in single leader one-year-old peach increased for more than four weeks following light pruning (main stem headed) which could have caused the slight but statistically significant trunk growth increase in the present study (Figure 6).

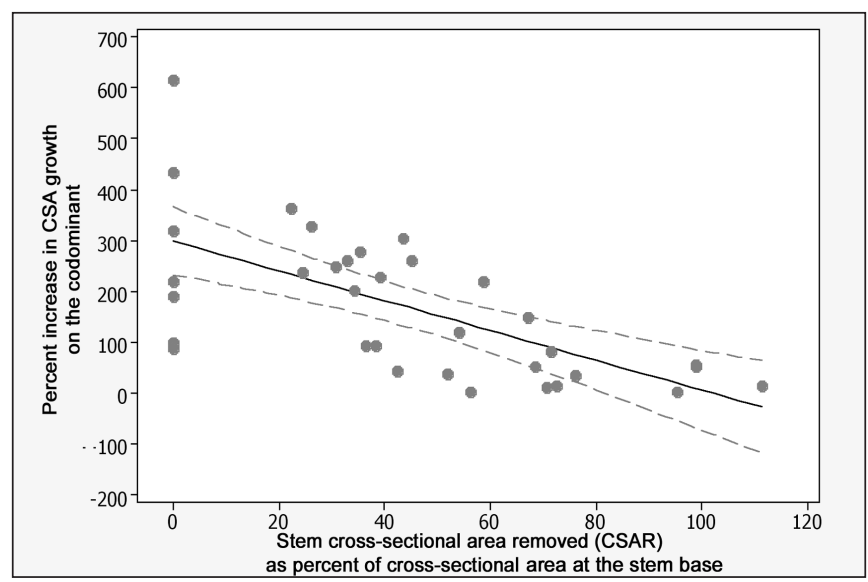

Figure 3. The percent increase in CSA of the codominant between May 2005 and May 2008 following removal of increasing amounts of stem cross-sectional area (CSAR). Percent increase $=298.7$ - 2.93 (CSAR), $\mathrm{r}^{2}=0.43$, slope and intercept $P<0.001$. The dotted lines represent a $95 \%$ confidence interval for the regression equation.

Although Stein (1955) and Clark (1955) also found trunk diameter enhancement with light pruning, research on many forest-grown conifers shows either a small reduction or no impact on trunk diameter growth from light crown raising (Hanley et al. 1995). Rate of trunk diameter growth in the present study was not reduced despite removing up to $75 \%$ of the foliage from the codominant stem. This might be due to the less than $30 \%$ (estimated) of total foliage on the tree removed with $75 \%$ TPS because only one stem on the tree was pruned. These were also young trees; stems of this diameter on older trees may have responded differently.

Since light pruning (25\% TPS) shifted growth from pruned codominant stem to unpruned leader (Figure 4) and increased trunk caliper, this might appear to be a good method of encouraging development of a dominant leader in live oak trees without sacrificing trunk growth. However, growth shifted for only one year suggesting this amount of pruning might be most appropriate in situations where regular pruning can be conducted. Trees with medium pruning severity (50\% TPS) also shifted growth to the unpruned leader, but unlike light pruning growth shifted for years one and three. Apparently, pruning the codominant stem removed enough resources to reduce wood accumulation in the pruned side while increasing accumulation on the unpruned side of the tree. The unpruned leader became the sink for increased allocation perhaps from the root system because of reduced demand and storage capacity on the codominant stem. Stored carbohydrates can be solubilized and translocated from roots to shoots in response to pruning (Singh and Thompson 1995). Pruning at $75 \%$ TPS dramatically reduced growth of the codominant as well as the diameter ratio of the codominant to the leader without affecting trunk caliper growth. This amount of pruning might be best suited for situations with longer pruning cycles or where dramatic growth reduction is warranted on codominant stems. Pruning with higher severities results in a large canopy void which could be aesthetically objectionable in some situations.

Increased pruning severity reduced growth on the codominant in proportion to amount of foliage removed. Langstron and Hellqvist (1991) found that removing $48 \%-75 \%$ of lower crown slowed growth for four years on Scots pine (Pinus sylvestris). 


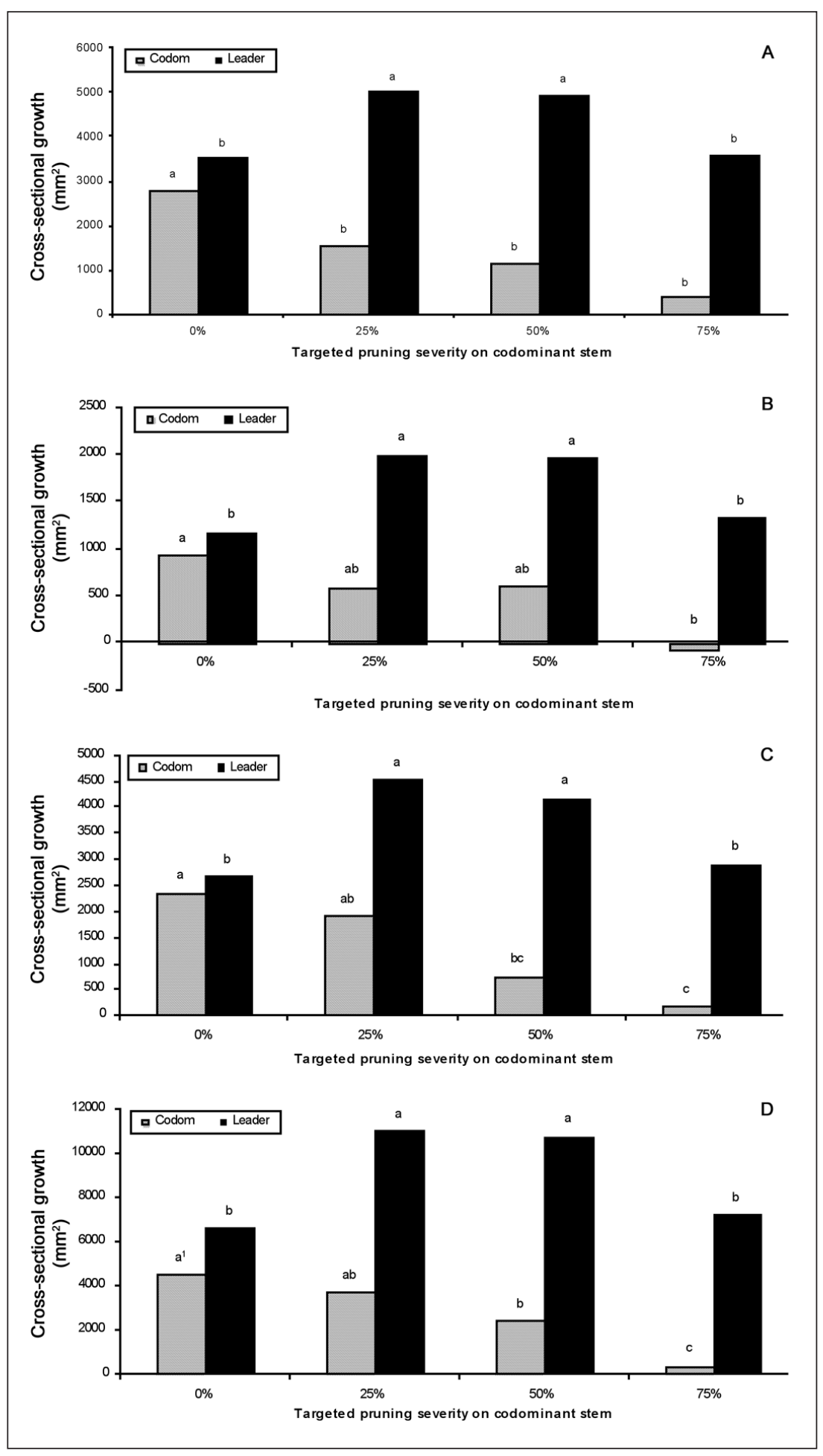

Figure 4. Cross-sectional area growth of codominant and leader stem following removal of targeted pruning severity $(0,25,50$, and $75 \%$ ): A) one, B) two, and C) three years after pruning, and D) combined data for all three years. Note: Within a stem type (codominant or leader), bars with the same letter are not statistically different at $P<0.05$. Codominant stems are not compared to leader stems.

The data showed the growth slowing effect using reduction and removal cuts lasted three years with the highest pruning severity. Few other studies have examined tree response to reduction prun- ing only one side of a crown other than Downer et al. (1994). Clearly this needs to be studied for a variety of tree types of different ages in different regions. The type of pruning cut (e.g., reduction versus removal), also needs to be evaluated for its impact on reduction in growth rate on pruned stems. Only Downer et al. (1994) compared pruning cut types, and showed that heading and removal cuts retarded growth similarly. Most studies done on forest trees have evaluated removal cuts from the lower and middle trunk, but not reduction cuts.

Gilman (2003), Kane et al. (2008), and others showed that smaller branch:trunk diameter ratios are associated with greater branch union strength. Eisner et al. (2002) also showed that branches with smaller ratios conduct less water per unit of a cross-sectional area. This might help partially explain how the branch protection zone functions by retarding movement of xylem inhabiting organisms such as fungi and bacteria. Structural pruning to induce a smaller stem diameter ratio as accomplished in this study at all pruning severities should make a tree structurally stronger, and perhaps more resistant to movement of decay organisms from branches to trunk.

Although there is inherent variability with using fresh leaf mass due to soil, climatic, weather, and species variation, regression coefficient (70.8, Figure 2) in the current study on $Q$. virginiana Highrise for branch CSA versus fresh leaf mass was similar to the 86.7 coefficient in $Q$. virginiana Cathedral Oak ${ }^{\circledR}$ (Grabosky et al. 2007). They showed that CSA on primary branches (those attached to the trunk) correlated well $\left(r^{2}=0.95\right)$ with actual fresh foliage mass on that branch, but the sum of CSA on the trunk above the union and adjacent primary branch was greater than CSA of trunk immediately below the union. This can be at least partially accounted for by hydraulic constriction represented by the branch protection zone found at the base of branches that are smaller than the parent branch (Eisner et al. 2002).

Pruning as performed in the current study created openings in the crown. Stem motion in windy weather was reduced when crown openings were large (Gilman et al. 2008), but openings created by pruning can close as branches change shape and move closer together in a windstorm if pruning severity is small (Vollsinger el at. 2005). Presumably (pers. obs.), openings close with time from a combination of growth from below on the subordinated stem and growth from above on the unpruned leader stem but how this happens has not been described. The current data provide evidence that growth-slowing effects on pruned codominant stems of live oak lasted three years at medium (50\%) and high $(75 \%)$ pruning severities in USDA hardiness zone $8 \mathrm{~b}$. Pruning with the lowest severity $(25 \%)$ was not as effective in slowing growth on codominant stems. Pruning with a moderate to high severity appears to be a good method of reducing 


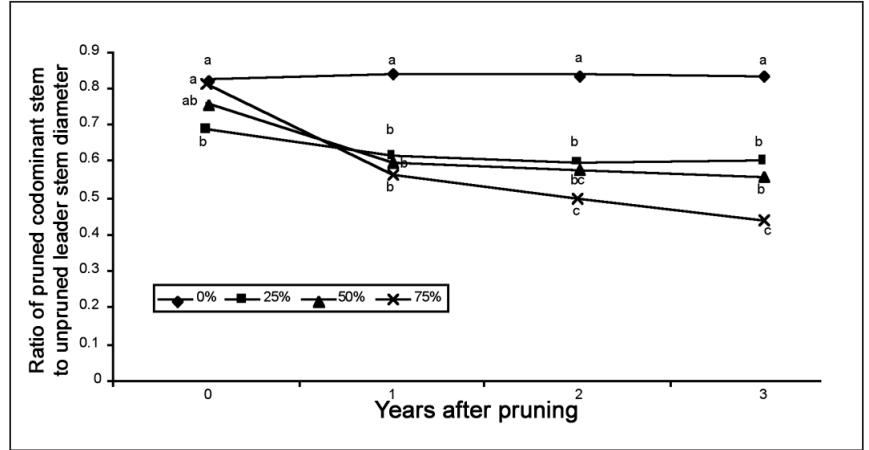

Figure 5. Diameter ratio of codominant to leader measured at the base of each stem at pruning (year 0 ) and in three subsequent years for four pruning severities: $0,25,50$ and $75 \%$ TPS. Within each year, numbers followed by the same letter are not statistically different at $P<0.05$.

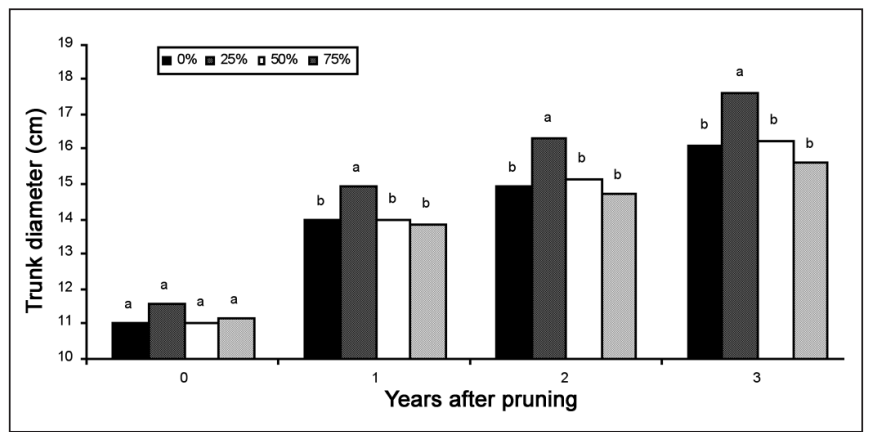

Figure 6. Trunk diameter $30 \mathrm{~cm}$ (12 in) from ground at pruning and in three subsequent years for four pruning severities $(0,25$, 50 and $75 \%$ ) from one codominant stem. Note: Within a year, bars with the same letter are not statistically different at $P<0.05$.

diameter ratio between pruned codominant stems and unpruned leader and should result in a stronger structure. Results may be different for different species and climates, and for larger trees.

\section{CONCLUSION}

Pruning reduced growth in linear proportion to amount of foliage removed on pruned codominant stems. This resulted in a reduction in size of the pruned codominant stem relative to the unpruned leader stem. Growth slowing effects from higher pruning severity lasted longer than for lower pruning severities. As much as $75 \%$ or more of a codominant stem can be removed without killing the stem on young live oaks pruned in this study. This provides guidelines for growers producing leaders when structurally pruning shade trees in a nursery, and for arborists pruning young trees in landscapes. It could also apply to younger outer portions of the crown of older trees where most structural pruning is conducted to resist storm damage.

Acknowledgments. Thank you to the TREE Fund and GreatSouthernTreeConference.org for funding of the project.

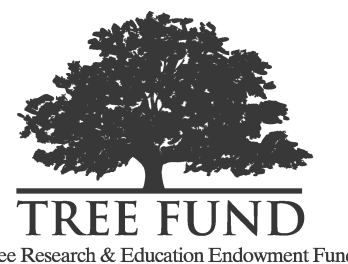

\section{LITERATURE CITED}

American National Standards Institute. 2008. American National Standard for tree care operations-Tree, Shrub, and Other Woody Pant Maintenance-Standards practices (Pruning). ANSI A300 (part 1). New York: American National Standards Institute.

Bredenkamp, B.V., F.S. Malan, and W.E. Conradie. 1980. Some effects of pruning on growth and timber quality of Eucalyptus grandis in Zululand. South African Forestry Journal 114:29-34.

Clark, F.B. 1955. Black walnut responds to pruning. Journal of Forestry 53:362-365

Downer, A.J., M. Shaw, and D. Pittenger. 1994. The effect of pruning on branch growth in two oak species. HortScience 29:550, Abstract \#815.

Eisner, N.J., E.F. Gilman, J.C. Grabosky, and R.C. Beeson. 2002. Branch junction characteristics affect hydraulic segmentation in red maple. Journal of Arboriculture 28:245-251.

Funk, D.T. 1979. Stem form response to repeated pruning of young black walnut trees. Canadian Journal of Forest Research 9:114-116.

Gilman, E.F. 2003. Branch to stem ratio affects strength of attachment. Journal of Arboriculture 29:291-294.

Gilman, E.F., and S. Lilly. 2008. Best management practices: pruning, second edition. International Society of Arboriculture, Champaign IL.

Gilman, E.F., J.C. Grabosky, F. Masters, and C. Harchick. 2008. Pruning affects tree movement in hurricane force wind. Arboriculture \& Urban Forestry 34:20-28.

Grabosky, J.C., E.F. Gilman, and C. Harchick. 2007. Use of branch cross sectional area for predicting pruning severity in young field-grown Quercus virginiana 'Cathedral' in Florida, US. Urban Forestry and Urban Greening 6:159-167.

Hanley, D.P., C.D. Oliver, D.A. Maguire, D.G. Briggs, and R.D. Fight. 1995. Forest pruning and wood quality of western North American conifers. College of Forest Resources, University of Washington, Seattle, Contribution, No. 77.

Kane, B., R. Farrell, S.M. Zedaker, J.R. Loferski, and D.W. Smith. 2008. Failure mode and prediction of the strength of branch attachments. Arboriculture \& Urban Forestry 34:308-316.

Langstrom, B., and C. Hellqvist. 1991. Effects of different pruning regimes on growth and sapwood area of Scots pine. Forest Ecology and Management 44:239-254.

Neilson, W.A., and E.A. Pinkard. 2003. Effects of green pruning on growth of Pinus radiata. Canadian Journal of Forest Research 33:2067-2073.

O'Hara, K. 1991. A biological justification for pruning in coastal Douglas-fir stands. Western Journal of Applied Forestry 6:59-63.

Pinkard, E.A., and C.L. Beadle. 1998. Effects of green pruning on growth and stem shape of Eucalyptus nitens (Deane and Maiden) Maiden. New Forests 15:107-126.

Rom, C.R., and D.C. Ferree. 1985. Time and severity of summer pruning influences on young peach tree net photosynthesis, transpiration, and dry weight distribution. Journal of American Society for Horticultural Science 110:455-461.

Singh, K.A., and F.B. Thompson. 1995. Effect on water potential, transpiration, regrowth, 14C-photosynthsate distribution and biomass production in Alnus glutinosa. Tree Physiology 15:197-202.

Smiley, E.T. 2003. Does included bark reduce the strength of codominant stems? Journal of Arboriculture 29:104-106.

Smiley, E.T., and B. Kane. 2006. The effects of pruning type on wind loading of Acer rubrum. Arboriculture \& Urban Forestry 32:33-40. 
Stein, W.I. 1955. Pruning to different heights in young Douglas fir. Journal of Forestry 53:352-355.

Vollsinger S., S.J. Mitchell, K.E. Byrne, M.D. Novak, and M. Rudnicki. 2005. Wind tunnel measurements of crown streamlining and drag relationships for several hardwood species. Canadian Journal of Forest Research 35:1238-1249.

Edward F. Gilman (corresponding author)

Professor

Environmental Horticulture Department

University of Florida

1533 Fifield Hall

Gainesville, FL 32611, U.S

egilman@ufl.edu

Jason Grabosky

Associate Professor

Ecology, Evolution and Natural Resources

Rutgers University

14 College Farm Road

New Brunswick, NJ 08901, U.S.

Résumé. Une branche codominante sur chacun des 48 Quercus virginiana Highrise ${ }^{\circledR}$ a été élaguée afin d'évaluer l'impact de la sévérité de l'élagage sur la réduction de croissance et la répartition de la croissance. La sévérité de l'élagage ciblé $(0,25,50$ ou $75 \%$ de feuilles et de branches sous-tendantes enlevés) a été évaluée en se basant sur l'estimation visuelle de deux personnes bien corrélées entre elles $\left(\mathrm{r}^{2}=\right.$ 0,87 ) au moyen du ratio de surface de la coupe transversale au niveau de la zone coupée par rapport à la surface de la coupe transversale à la base de la tige codominante élaguée. On a aussi évalué la croissance de la tige élaguée par rapport à la tige non élaguée, plus particulièrement dans les 12 premiers mois suivants l'élagage. Avec l'augmentation de la sévérité de l'élagage, on a observé une diminution accrue de la croissance de la tige élaguée proportionnelle au feuillage enlevé. Dans chacune des trois années suivant l'élagage, la section transversale de la tige non élaguée s'est accrue plus chez les arbres qui avaient fait l'objet d'un élagage ciblé à un taux de 25 ou de $50 \%$ que chez ceux ayant subi un taux de $75 \%$ ou encore qui n'avaient eu aucun élagage. Le changement de croissance entre la portion élaguée et celle non élaguée a occasionné une diminution du ratio de diamètre entre les deux tiges, ce qui pourrait résulter en un point d'attache plus solide. Le changement de ration entre les diamètres a été le plus prononcé avec un degré de sévérité d'élagage de $75 \%$.

Zasummenfassung. Von 48 ähnlichen $Q$. virginiana-Bäumen wurde jeweils ein kodominanter Stämmling entfernt, um die Auswirkungen des Rückschnitts auf das Wachstum und die Teilung zu bewerten. Der angezielte Rückschnitt $(0,25,50$ oder $75 \%$ der Blätter und Zweige entfernt) basierte auf den Schätzungen von zwei Menschen und korrelierte gut $\left(r^{2}=0,87\right)$ mit der durchschnittlichen Stammfläche, die entfernt wurde: die Schnittfläche an der Basis des entnommenen Stämmlings. Der Rückschnitt reduzierte besonders in den ersten folgenden 12 Monaten das Wachstum an den entnommenen Stämmlingen im Gegensatz zum ungeschnittenen Leittrieb. Stärkerer Rückschnitt reduzierte das Wachstum an den eingekürzten Stämmlingen in Proportion zu dem entfernten Laub. In allen drei Jahren nach dem Rückschnitt vergrößerte sich der Querschnitt des ungeschnittenen Leittriebs mehr an Bäumen, die $25 \%$ bzw. 50 $\%$ Rückschnitt erhielten, während es sich bei $75 \%$ Rückschnitt oder gar keinem Rückschnitt unwesentlich vergrößerte. Ein Wechsel im Wachstum von den geschnittenen zu den ungeschnittenen Teilen des Baumes reduzierte das Durchmesserverhältnis zwischen den beiden Stämmen, was die Verbindung stärken soll. Bei $75 \%$ Rückschnitt veränderte sich das Durchmesserverhältnis am meisten.
Resumen. Se podó una rama codominante de cada uno de 48 árboles similares de Quercus virginiana Highrise ${ }^{\circledR}$ para evaluar el impacto de la severidad de la poda en la disminución del crecimiento. La intensidad de la poda $(0,25,50$ o $75 \%$ del follaje y las ramas removidas) estuvo basada en estimaciones visuales de dos personas. La correlación de estas estimaciones fue buena $(\mathrm{r} 2=0.87)$ con la relación de área removida: área en la base de la rama podada. La poda redujo el crecimiento de la sección en los tallos codominantes, comparado con el líder que no fue podado, especialmente durante los primeros 12 meses posteriores a la poda. El incremento en la severidad de la poda redujo el crecimiento del área trasversal de los tallos podados en proporción a la cantidad de follaje removido. En cada uno de los tres años posteriores a la poda, el área de la sección del líder no podado incrementó más en los árboles con intensidad de poda de $25 \%$ o $50 \%$ que los árboles podados con el $75 \%$ de intensidad o árboles no podados. El cambio en el crecimiento de la porción podada a la no podada del árbol redujo la relación del diámetro entre los dos tallos, lo cual podría hacer más fuerte la unión. La relación del diámetro cambió más para el $75 \%$ de severidad de poda. 